\title{
Pengembangan Desa Wisata Adat Using Kemiren Melalui Pendekatan Penta Helix
}

Tedy Winarno ${ }^{1}$, M. Mas'ud Said ${ }^{2}$, Hayat ${ }^{3}$

Universitas Islam Malang, Jl. Mayjen Haryono No. 193 Malang

Corresponding Author: tedywinarno148@gmail.com

\section{Keyword:}

Development;

Traditional Tourism

Village;

Penta Helix
Kata Kunci:

Pengembangan;

Desa Wisata Adat;

Penta Helix

\begin{abstract}
The purpose of this study is to discuss the development of the Using Kemiren Traditional Tourism Village through the Penta Helix concept. As we know, the Penta Helix concept is a collaborative concept between five stakeholders, namely the government, the public, the private sector, academia, and the mass media. We used a descriptive method, with a qualitative approach in which researchers used information sources in the field to seek as much information as possible. In practice, the development of the Using Kemiren Traditional Tourism Village still relies on two main actors, namely the Village Government and the Kemiren Society. So far, the results obtained are quite good. This can be seen from the number of tourists who continue to increase every year. However, if you look at the potential possessed by Kemirin, the opportunity to increase the number of tourists and develop local potential is still very wide open. Therefore, other actors or stakeholders are needed who can support the development of the Using Kemiren Traditional Tourism Village.
\end{abstract}

\begin{abstract}
Abstrak: Tujuan penelitian ini adalah membahas tentang pengembangan Desa Wisata Adat Using Kemiren melalui konsep Penta Helix. Konsep Penta Helix merupakan konsep kolaborasi antara lima pemegang kepentingan yakni pemerintah, masyarakat, swasta, akademisi, dan media massa. Kami menggunakan metode deskriptif, dengan pendekatan kualitatif dimana peneliti memanfaatkan sumber informasi di lapangan guna mencari informasi sedalam mungkin. Dalam prakteknya, pengembangan Desa Wisata Adat Using Kemiren masih mengandalkan dua aktor utama yakni Pemerintah Desa dan Masyarakat Kemiren. Sejauh ini, hasil yang di dapatkan memang sudah cukup baik. Hal ini dapat dilihat dari jumlah wisatawan yang terus mengalami peningkatan setiap tahunnya. Akan tetapi jika melihat potensi yang dimiliki oleh Kemirin, peluang untuk meningkat jumlah wisatawan serta mengembangkan potensi lokal masih sangat terbuka lebar. Oleh sebab itu dibutuhkan aktor atau pemangku kepentingan lainnya yang dapat mendukung pengembangan Desa Wisata Adat Using Kemiren.
\end{abstract}

Informasi Artikel: Disubmit: 02-10-2021, Revisi: 10-11-2021, Diterima: 13-11-2021

\section{PENDAHULUAN}

Indonesia merupakan sebuah negara dengan anugerah adat budaya yang sangat luar biasa (Brata, 2016; Setyaningrum, 2018). Adat serta budaya yang dimiliki oleh bangsa Indonesia menjadi kekuatan yang telah berhasil menyatukan berbagai macam latar belakang menjadi satu kesatuan dalam bingkai bhinneka tunggal ika (Suparlan, 2014; Lestari, 2016). Namun demikian seiring dengan berkembangnya zaman, adat budaya mengalami degradasi yang cukup signifikan. Menurut Hayat (2019), ada beberapa faktor yang mempengaruhi tingkat degradasi budaya yakni 
teknologi yang dinamis, perilaku hedonisme, sikap individualistik masyarakat, serta demoralisasi perilaku. Berbagai upaya telah dilakukan oleh banyak pihak dalam menjaga agar adat budaya yang kita miliki tidak lenyap ditelan zaman. Salah satu upaya yang dilakukan adalah melalui sektor pariwisata.

Dewasa ini kita dapat menemui berbagai inovasi di bidang pariwisata yang sekaligus juga sebagai sarana pelestarian adat budaya. Salah satu inovasi yang kini tengah berkembangan pesat di Indonesia adalah sebuah konsep pengembangan pariwisata berbasis Masyarakat atau community based tourism dimana Masyarakat berperan aktif di dalamnya (Pantiyasa, 2011; Prasiasa, 2013; Rusyidi \& Fedryansah, 2018). Pemberdayaan Desa Wisata merupakan bentuk dari pariwisata berbasis Masyarakat dimana potensi lokal desa diangkat menjadi sebuah suguhan yang menarik sehingga dapat menarik minat wisatawan untuk datang berkunjung (Andayani, Martono \& Muhamad, 2017; Kusniawati, 2017; Trisnawati, Wahyono \& Wardoyo, 2018). Konsep Desa Wisata merupakan salah satu role konsep pengembangan pariwisata berbasis kemasyarakatan. Yudha (2010:42) mengatakan bahwa perkembangan pariwisata, sejalan dengan dinamika yang berkembang, telah merambah berbagai terminologi seperti, sustainable tourism development, village tourism, dan ecotourism, yang merupakan pendekatan pengembangan kepariwisataan yang berupaya untuk menjamin agar wisata dapat dilaksanakan di daerah tujuan wisata bukan di perkotaan.

Fenomena pemberdayaan Desa Wisata di Indonesia terus berkembang pesat seiring dengan banyaknya media massa yang menyebarluaskan keberhasilan program ini. Kabupaten Banyuwangi yang terletak di ujung timur pulau jawa misalnya, dengan pesona alam yang begitu luar biasa mulai dari hamparan pantai, pegunungan, hutan yang masih asli, hingga kekayaan adat istiadat yang masih kental dipegang oleh Masyarakat. Kekayaan adat istiadat yang dimiliki oleh Banyuwangi dapat dilihat dari kehidupan Masyarakat Suku Using yang merupakan suku asli Banyuwangi. Tidak heran jika berkunjung kebeberapa daerah yang mayoritas warganya adalah Suku Using kita akan menjumpai praktek-praktek adat istiadat seperti tari-tarian, cara berpakaian, berkomunikasi dan lain sebagainya.

Salah satu tempat yang masih sangat teguh dalam mempertahankan eksistensi adat budaya di Banyuwangi adalah Desa Wisata Adat Using Kemiren. Kekayaan adat budaya yang dimiliki oleh Masyarakat Kemiren tentu merupakan sebuah anugerah yang tidak ternilai harganya. Oleh sebab itu menjaga, melestarikan, serta mendayagunakan adat budaya yang dimiliki mejadi tanggung jawab bersama. Salah satu cara yang dapat dilakukan tentu dengan mengenalkannya kepada halayak umum melalui pariwisata. Seperti halnya kebudayaankebudayaan di tempat lain, adat budaya yang dimiliki oleh Masyarakat Kemiren tentu memiliki tantangan dan permasalahan yang dihadapi dalam upaya mempertahankan eksistensinya. Adapun perkembangan potensi kepariwisataan di Kemiren cenderung kurang optimal. Hal itu bisa dilihat dari jumlah kunjungan wisatawan yang datang ke Desa Wisata Adat Kemiren pada tahun 2019 hanya sebesar 18.436 wisatawan atau hanya $0.4 \%$ dari jumlah wisatawan yang datang ke Banyuwangi sebanyak 5,6 juta wisatawan (Muthiara, 2020: 12-13).

Persentase tersebut tentu bisa dibilang masih belum maksimal apabila dibandingkan dengan potensi yang dimiliki oleh Desa Wisata Adat Kemiren. Selain itu pengelolaan pariwisata berbasis keberbudayaan suku Using dengan masih melibatkan pemerintah sebagai pemain yang paling dominan atas keterlibatan orang diluar pemerintah. Artinya bahwa Pemerintah Daerah dalam hal ini Pemerintah Desa Kemiren mengambil porsi cukup besar dalam mengelola kepariwisataan berbasis kebudayaan di Kemiren. Sementara tantangan dan permasalahan pariwisata terutama yang memiliki basis pada kebudayaan akan terus berkembangan. Sehingga pengembangan pariwisata di Kemiren akan terhambat apabila hanya mengandalkan kekuatan dari Pemerintah Desa sebagai aktor utamanya. Karena tentu Pemerintah Desa memiliki keterbatasan pembiyaan yang menjadi sokongan utama pengembangan pariwisata berbasis kebudayaan di Desa Wisata Adat Using Kemiren.

Sejauh ini, peran Pemerintah Desa dan sebagian Masyarakat Desa Kemiren belum bisa memaksimalkan potensi kekayaan adat budaya yang dimiliki. Sehingga dibutuhkan aktor lain yang bisa menyokong fungsi dan tugas Pemerintah Desa dalam memaksimalkan potensi tersebut. Aktor-aktor tersebut antara lain Swasta, Akademisi dan Media Massa atau yang kemudian disebut 
dengan kolaborasi konsep Penta Helix. Berdasarkan pemaparan tersebut, mendorong penulis untuk melakukan penelitian berkaitan dengan pengembangan wisata desa adat dengan memanfaatkan konsep Penta Helix di Desa Wisata Adat Using Kemiren Kecamatan Glagah Kabupaten Banyuwangi.

\section{METODE PENELITIAN}

Metode yang digunakan dalam penelitian ini menggunakan metode penelitian kualitatif dengan tujuan untuk melakukan penelitian menggunakan sasaran yang ada sebagai sarana dalam menggali sebanyak mungkin data mengenai sasaran penelitian. Sedangkan sifat penelitian berupa deskriptif dengan maksud agar dapat menggambarkan, meringkaskan berbagai informasi, kondisi, situasi, atau berbagai variabel.

Apabila berdasar pada teori yang dikemukakan oleh Kirk dan Miller (1986:9), mereka berpendapat bahwa penelitian jenis kualitatif merupakan sebuah tradisi tertentu dalam ilmu pengetahuan sosial yang secara fundamental bergantung pada pengamatan manusia baik itu dari dalam kawasan juga dalam peristilahannya penelitian kualitatif dari sisi definisi lainnya dikemukakan bahwasanya hal tersebut merupakan penelitian yang memanfaatkan wawancara terbuka dalam menelaah serta memahami pandangan, sikap juga perilaku individu ataupun kelompok. Oleh sebab itu, dalam penelitian ini akan memaparkan secara deskriptif untuk menggambarkan secara sistematis berkaitan tentang Penerapan konsep Penta Helix dalam Upaya pengembangan Desa Wisata Adat Using Kemiren serta menemukan faktor pendukung dan penghambat dalam memaksimalkan potensi budaya yang dimiliki.

\section{HASIL DAN DISKUSI}

Desa Wisata Adat Using Kemiren terletak di Kecamatan Glagah Kabupaten Banyuwangi. Berbekal konsistensi mayarakat Kemiren dalam memegang serta melestarikan adat istiadat serta budaya suku Using, pada tahun 1995 Desa Kemiren resmi ditetapkan sebagai Desa Adat Using Kemiren melalui surat keputusan Gubernur Jawa Timur Basofi Sudirman. Berdasar pada Undangundang Nomor 6 Tahun 2014 tentang Desa, Desa Adat dapat diartikan sebagai kesatuan masyarakat hukum yang memiliki batas wilayah yang berwenang untuk mengatur urusan pemerintahan, kepentingan masyarakat setempat berdasarkan prakarsa masyarakat, hak asal usul, dan/atau hak tradisional yang diakui dan dihormati dalam sistem pemerintahan Negara Kesatuan Republik Indonesia.

Semantara untuk membangun sebuah desa menjadi desa adat, menurut Prasetyo (2014:148) terdapat delapan unsur yang harus dipenuhi yakni atraksi, akomodasi, institusi atau kelembagaan, fasilitas pendukung, transportasi, sumber daya alam dan sosial budaya, masyarakat serta pasar domestik dan mancanegara. Desa Adat Using Kemiren dengan segenap anugerahnya memiliki banyak sekali potensi wisata terutama yang berbasis pada budaya. Sehingga sejauh ini, telah ada upaya dalam mengembangkan potensi pariwisata tersebut terutama oleh Pemeritah Desa dan juga Masyarakat setempet.

\section{Potensi Desa Wisata Adat Using Kemiren}

Pengembangan potensi wisata di Desa Kemiren saat ini memang telah menunjukan grafik yang meningkat dibandingan dengan satu dekade yang lalu. Ada begitu banyak inovasi pariwisata yang telah dilakukan terutama oleh Pemerintah Desa Kemiren sejauh ini. Selain tentu dukungan dari Pemerintah Daerah Kabupaten Banyuwangi yang juga ikut andil dalam pelaksanaan berbagai program kemandirian pariwisata di Desa Adat Using Kemiren. Adapun potensi Desa Wisata Adat Using Kemiren sebagai berikut :

1. Rumah Adat Using Kemiren (Heritage)

Rumah adat using Kemiren sejatinya berperan sama seperti halnya rumah-rumah adat lainnya. Rumah adat tidak hanya sebagai tempat meneduh dan beristirahat saja, akan tetapi juga menjadi identitas kekayaan masyarakat yang memiliki makna historis yang begitu dalam. termasuk rumah adat using kemiren. Secara filosofis bentuk, rumah adat suku Using memiliki tiga bagian utama yakni Tikel Balung yang melambangkan lika-liku kehidupan rumah tangga, 
Cerocongan yang melambangkan bersatunya laki-laki dan perempuan dalam pernikahan, dan Baresan melambangkan rumah tangga yang sudah beres atau berjalan baik.
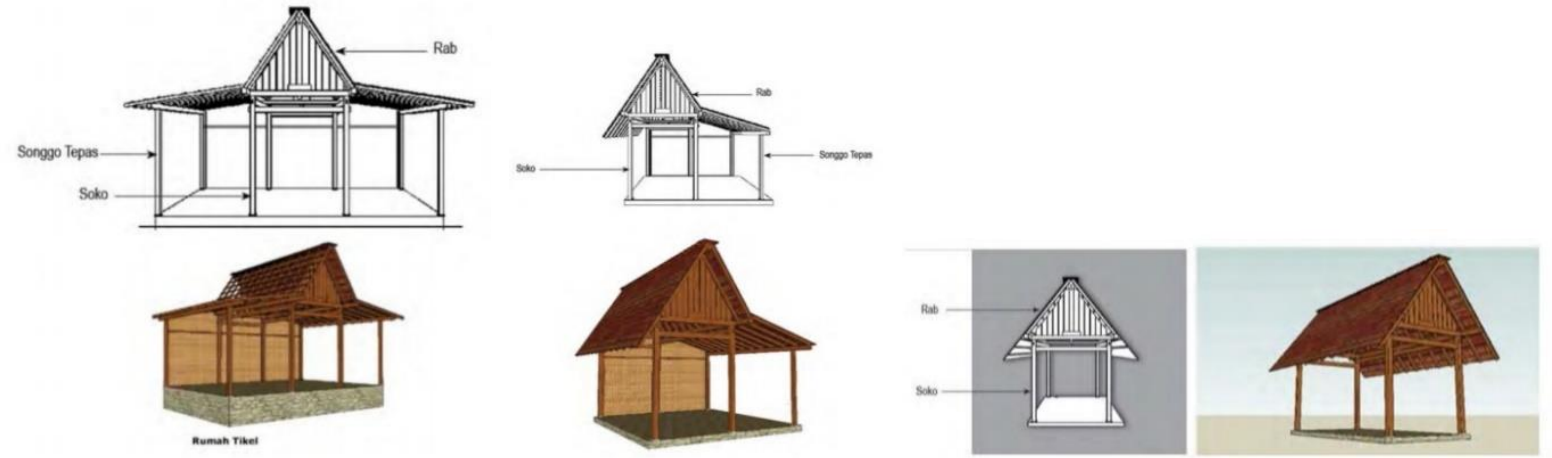

Gambar 1. Bentuk Rumah Model Tikel Balung, Cerocongan, dan Baresan

Sumber: website Desa Kemiren

Saat ini Pemerintah Desa Kemiren telah membangun situs rumah adat Using Kemiren yang berada di daerah bernama Sukosari. Situs rumah adat tersebut berjumlah 10 rumah yang terintegrasi dengan sanggar seni dan aula adat. Lokasi situs yang dilewati aliran sungai dan berada di tengah areal persawaan menambah suasana asri khas pedesaan. Selain sebagai upaya pelestarian, situs ini juga dijadikan sebagai pusat studi adat dan budaya Using mulai dari upacara adat, penampilan-penampilan budaya sepeti tari, barong, music dan lain sebagainya. Sebenarnya, rumah-rumah warga di desa Kemiren mayoritas masih mempertahankan konsep dan arsitektur khas Suku Using. Namun memang layaknya rumah pakai yang telah berusia lama, bangunannya pun sudah terlihat biasa. Hal inilah yang menginspirasi Pemerintah Desa Kemiren kemudian membangun situs rumah adat Using Kemiren yang ada saat ini. Pembangunan situs inipun tidak hanya berhenti sampai disini, saat ini Masyarakat adat, bersama Pokdarwis dan Pemerintah Desa tengah membangun lagi situs rumah adat untuk memperkaya aset pariwisata di desa Kemiren.

2. Rangkaian Banyuwangi Festival di Desa Wisata Adat Using Kemiren

Banyuwangi saat ini dikenal oleh khalayak umum berkat sektor pariwisatanya yang mempesona. Salah satu yang menjadi ikon dari daerah ujung timur pulau jawa ini adalah rangkaian Banyuwangi Festivalnya yang sejak pertama dilaksanakan pada tahun 2012 hanya dengan 10 event hingga saat ini adalah lebih dari 100 event diselenggarkan setiap tahunnya. Sementara di Kemiren, ada tiga agenda besar yang masuk ke dalam rangkaian Banyuwangi Festival yakni tradisi barong ider bumi, festival tumpeng sewu dan festival ngopi sepuluh ewu.

Pertama, tradisi barong ider bumi. Tradisi barong ider bumi merupakan salah satu bentuk kekayaan budaya masyarakat Kemiren. Ditinjau dari penamaannya, barong merupakan sebutan bagi mitologi masyarakat terutama di Jawa dan Bali yang berupa seperti binatang berkaki empat dengan kepala identik dengan kepala singa. Sementara ider dalam bahasa Using diartikan sebagai berkeliling dan bumi diartikan sebagai tempat berpijak. Sehingga dari pemahaman diatas dapat disimpulkan bahwa barong ider bumi merupakan sebuah tradisi barong yang dilakukan dengan cara berkeliling ke seluruh wilayah tempat tinggal di desa. Tradisi barong ider bumi sendiri sudah dilakukan sejak tahun 1840 dimana saat itu Masyarakat Kemiren sedang dilanda pageblug yang berkepanjangan. Akhirnya para sesepuh desa berinisiatif berziarah ke makam Buyut Cili yang dianggap dan dipercayai sebagai leluhur desa Kemiren. Akhirnya setelah melaksanakan ziarah ke makam Buyut Cili, warga banyak yang diberi wangsit melalui mimpi agar melaksanakan selamatan dengan cara berkeliling desa. Sejak saat itulah barong ider bumi rutin dilaksanakan hingga saat ini setiap tanggal 2 Syawal atau hari kedua lebaran.

Sejak tahun 2014, barulah tradisi barong ider bumi ini dimasukan ke dalam kalender Banyuwangi Festival oleh Pemerintah Daerah Kabupaten Banyuwangi yang saat menjadi acara ikonik di Banyuwangi. Tradisi barong ider bumi sendiri dilaksanakan dengan iring-iringan yang dimulai dengan dua orang pembawa umbul-umbul atau bendera kebesaran desa Kemiren, kemudian disusul dengan macan-macanan, pitik-pitikan, barong lengkap dengan iringan music khas Using, kemudian barisan ibu-ibu dengan bawaan berbagai macam makanan, jaran kecak, kelompok rebana, aparat pemerintah dan terakhir para pemusik kuntulan. Uniknya di akhir 
acara, ketika sampai di garis finis seluruh warga akan berkumpul untuk berdoa yang dibawakan dengan bahasa Using dan Arab lalu diakhiri dengan makan bersama makanan khas Kemiren yakni pecel pithik.

Dimasukannya barong ider bumi ke dalam rangkaian Banyuwangi Festival tentu merupakan wujud dari apresiasi Pemerintah Daerah secara khusus tentang pentingnya pelestarian budaya. Hal ini seolah seperti pepatah "gayung bersambut" dimana Masyarakat Banyuwangi pada khususnya dan juga Masyarakat Dunia pada umumnya juga ikut andil dalam memberikan apresiasi pelestarian budaya melalui tradisi barong ider bumi. Sejak saat itu pula, kunjungan wisatawan ke Desa Wisata Adat Using Kemiren terus mengalami peningkatan terutama pada saat event-event budaya berlangsung salah satu pada saat tradisi barong ider bumi dilaksanakan.

Kedua, festival tumpeng sewu. Seperti yang tergambar pada penamaanya, festival tumpeng sewu merupakan sebuah event dimana Masyarakat desa Kemiren menyuguhkan lebih dari 1000 tumpeng untuk dimakan bersama. Kegiatan ini dilaksanakan pada tanggal 1 dzulhijjah atau sepuluh hari sebelum hari raya idhul adha setiap tahunya. Tujuan diselenggarakannya tradisi ini sejatinya adalah selamatan warga desa yang diniatkan untuk menolak balak dengan cara bersedekah makanan. Uniknya, festival tumpeng sewu ini dilaksanakan di sepanjang jalan utama desa. Sehingga sejak sore hari, jalan desa akan ditutup dan bagi wisatawan yang ingin bergabung harus berjalan kaki dari pintu masuk desa menuju tempat acara sebagai bentuk penghoratan. Kegiatan festival tumpeng sewu ini akan dimulai selepas sholat magrib dengan diawali doa bersama yang dipimpin oleh sesepuh desa. Setelah itu kemudian seluruh warga desa yang telah bersiap di depan rumah masing dengan berbagai macam bentuk tumpeng mulai menikmatinya bersama dengan keluarga dan para tamu serta wisatawan yang datang. Yang lebih menarik lagi adalah siapapun boleh ikut menikmati tumpeng dan suguhan yang ada secara gratis. Tidak heran setiap pelaksanaannya, festival tumpeng sewu berhasil mendatang ribuan wisatawan baik dari wilayah Banyuwangi bahkan sampai mancanegara.

Hal ini tentu tidak terlepas dari peran Pemerintah Daerah yang berhasil mengemas promosi dengan memasukkan tradisi tumpeng suwe ke dalam rangkaian Banyuwangi Festival. Sama seperti festival barong ider bumi, sejak tahun 2013 kegiatan festival tumpeng sewu tidak pernah sepi dari pengunjung. Dan ketiga, festival ngopi sepuluh ewu. Sama seperti halnya dua festival sebelumnya, dilihat dari namanya saja sudah bisa ditebak bahwa kegiatan yang satu ini merupakan acara minum kopi bersama lebih dari sepuluh ribu cangkir. Tujuan dilaksanakannya kegiatan festival ngopi sepuluh ewu ini tidak hanya sekedar ajang meminum kopi biasa saja, akan tetapi sebagai upaya dalam memupuk tali persaudaran antar sesama anak bangsa. Dalam festival ini, tidak ada perbedaan sama sekali, baik tua maupun muda, laki-laki maupun perempuan, baik yang berangkat dengan jalan kaki, dengan sepeda motor maupun yang bermobil tumplek blek jadi satu. Ada berbagai macam varian kopi khas Banyuwangi yang disuguhkan dalam festival ini mulai arabica, robusta hingga house bland. Yang lebih membanggakan lagi, bahwa seluruh pelaksanaan kegiatan ini adalah swadaya dari Masyarakat Kemiren sendiri, pemerintah hanya memberikan dukungan minor saja. Kearifan lokal yang dibalut dengan keramahan Masyarakat inilah yang membuat jalan poros desa sepanjang tiga kilometer penuh sesak saat acara ini berlangsung.

Ketiga tradisi diatas yang kemudian dibingkai dalam rangkaian Banyuwang Festival tentu tujuan akhirnya adalah agar terciptanya iklim atau perputaran roda perekonomian. Sebab tentu semakin banyak wisatawan yang datang ke Kemiren, maka semakin banyak pula akivitas perekonomian yang berjalan baik UMKM, Kuliner maupun homestay.

3. Pengembangan UMKM, Homestay dan Kuliner

Tingkat kesejahteraan sekelompok masyarakat secara sederhana dapat dilihat dari tingkat perekonomiannya. Semakin tinggi pendapatan perkapitanya maka bisa dipastikan tingkat kesejahteraan akan semakin tinggi pula. Hal ini pun juga berlaku di Desa Wisata Adat Using Kemiren. Berbagai inovasi terus dilancarkan demi tercapainya peningkatan kesejahteraan masyarakat termasuk di dalamnya digitalisasi. Mulai dari UMKM melalui BUM-Des, pengelolaan homestay, dan wisata kuliner. Saat ini di Kemiren, ada berbagai jenis UMKM baik yang dikelola oleh Kelompok Sadar Wisata (Pokdarwis) maupun oleh Masyarakat Kemiren sendiri. Mulai dari 
produk kopi khas Banyuwangi, cinderamata hingga berbagai usaha lainnya. Selain itu, Pemerintah Desa melalui karang taruna dan pokdarwis berinovasi dengan mengadakan Pasar Kampoeng Using Kemiren. Pasar ini merupakan pasar yang menjajakan makanan-makanan serta berbagai macam cemilan khas Using setiap hari minggu pagi. Lokasinya berada tepat di gang sebelah barat kantor desa Kemiren. Kehadiran Pasar Kampoeng Using Kemiren ini tentu menambah geliat perekonomian yang terbukti tidak pernah sepi pengunjung. Uniknya lagi, seluruh penjual yang berada di pasar ini kompak menggunakan pakaian adat suku Using saat berjualan, sehingga menambah kesan asri khas pedesaan.

Selain UMKM, Pemerintah Desa juga memacu perekonomian warganya dengan mendirikan homestay. Status Kemiren sebagai desa wisata adat tentunya harus dimanfaatkan dengan baik oleh masyarakat. Di Kemiren sendiri hingga saat ini, terdapat sebanyak 43 homestay dan 1 hotel. Saat ini memang tren menginap di homestay banyak menjadi pilihan wisatawan saat berlibur. Selain harganya yang lebih terjangkau, keramahan yang mereka dapatkan di homestay tidak akan di dapatkan jika merekan menginap di hotel. Ditambah lagi, homestay-homestay yang ada di Kemiren sangat kental dengan nuansa rumah adat khas suku Using, sehingga menambah kesan nyaman dan kekeluargaan.

Wisata kuliner juga tidak kalah menjadi salah satu penyokong perekonomian warga desa. Ada setidaknya 5 warung makan atau bisa disebut restauran desa yang ada di Kemiren. Jumlah ini belum termasuk warung-warung kecil miliki warga yang lainnya. Lima warung diatas yang dimaksud adalah warung makan yang skalanya sudah seperti restaurant pada umumnya. Menumenu khas Using seperti pecel pithik, uyah ayem, kue cucur, kue kelemben aneka kopi khas Banyuwangi dan masih banyak lagi menjadi senjata utama dalam menarik minat wisatawan untuk berkunjung. Keunikan-keunikan warung makan di Kemiren adalah bangunannya yang menggunakan arsitektur suku Using dan juga lokasinya yang berada di areal persawahan menambah nikmatnya makan. Dalam mengembangankan UMKM, homestay dan wisata kuliner memang akan terus menemui tantangannya tersendiri. Oleh sebab itu, dibutuhkan keuletan pihak-pihak terkait agar dapat terus menelurkan inovasi-inovasi baru untuk semakin meningkatkan kualitas kesejahteraan Masyarakat Kemiren.

\section{Pengembangan Desa Wisata Adat Using Kemiren melalui Konsep Penta Helix}

Upaya pengembangan Desa Wisata Adat Using Kemiren terus dilakukan baik oleh Pemerintah maupun Masyarakat. Namun seperti yang tertera pada data diatas, bahwa jumlah wisatawan yang berkunjung ke Kemiren masih diangka 18.436 wisatawan atau hanya $0.4 \%$ dari jumlah wisatawan yang datang ke Banyuwangi sebanyak 5,6 juta wisatawan. Apabila melihat potensi yang dimiliki oleh Kemiren tentu angka diatas masih sangat mungkin untuk terus dipompa dan dinaikkan. Adapaun cara menaikan angka kunjungan wisatawan tidak lain dan tidak bukan hanya dengan terus berinovasi. Sebab dalam mengelola sebuah produk kebijakan, tidak boleh hanya berhenti pada satu kebijakan saja. Akan tetapi harus terus berkembang dan mencari inovasi-inovasi baru sesuai dengan tantangan yang dihadapi. Salah satu inovasi yang dapat dijalankan oleh pemerintah terutama Pemerintah Desa Kemiren adalah pengembangan Desa Adat Using Kemiren melalui konsep Penta Helix. Penta Helix menurut Halibas dkk (2017) adalah konsep pengembangan sosial-ekonomi melalui kolaborasi dan kemitraan antara, Pemerintah, Masyarakat, Swasta, Akademisi, dan Media Sosial.

Sejauh ini, pengembangan pariwisata yang ada di Kemiren masih mengandalkan dua aktor utama yakni Pemerintah Desa Kemiren dan sebagian Masyarakat. Sementara inovasiinovasi yang ditelurkan masih menggunakan metode lama, yakni menunggu usulan dari Masyarakat. Sehingga hal ini tentu bisa menjadi penghambat laju pengembangan Desa Wisata Adat Using Kemiren. Oleh sebab itu apabila ditinjau melalui konsep Penta Helix, maka sebagai berikut:

\section{Pemerintah Desa Kemiren}

Pemerintah Desa Kemiren memang menjadi satu dari dua aktor utama dalam pengembangan Desa Wisata Adat Using Kemiren selain Masyarakat. Peran pemerintah desa dalam konsep Penta Helix sejatinya hanya berfokus pada regulator dan juga fasilitator. Peranperan tersebut mencakup penyusunan peraturan atau dasar hukum dalam melaksanakan kebijakan-kebijakan Desa Wisata Adat Using Kemiren. Kemudian menyediakan fasilitas pelatihan 
yang relefan dengan kebutuhan Masyarakat Kemiren terutama dalam hal pelestarian budaya. Dan juga memonitoring berjalannya pengembangan Desa Wisata Adat Using Kemiren agar tetap bisa berjalan sesuai dengan visi misi pemerintah desa dan tujuan utama guna mensejahterakan Masyarakat.

Sejauh ini berdasarkan penelitian yang sudah penulis laksanakan. Pemerintah Desa Kemiren sudah bisa menjalankan ketiga fungsi diatas, hal ini dapat dilihat dari produk hukum yang sudah disahkan mulai dari Surat Keputusan Desa Adat, Surat Keputusan Desa Wisata, kemudian Surat Keputusan berkaitan dengan pelestarian budaya dan lain sebagainya. Pemerintah Desa Kemiren juga rutin mengadakan kordinasi dengan Masyarakat mulai dari unsur tokoh adat, tokoh agama, pelaku seni, pelaku usaaha dan tentu para pemudanya. Hanya saja memang dalam hal kerjasama dengan pihak swasta, Pemerintah Desa Kemiren masih belum bisa memaksimalkan potensi yang ada. Menurut Kepala Desa Kemiren, Pemerintah desa tidak memulai kerjasama dengan menawarkan ke berbagai pihak swasta. Pemerintah Desa Kemiren berfokus pada peningkatan kualitas sumber daya manusianya. Sehingga diharapkan dengan peningkatan kualitas pemanfaatan potensi lokal, akan menarik pihak swasta secara otomatis.

\section{Masyarakat}

Masyarakat dalam konsep Penta Helix memiliki peran utama dalam pengembangan Desa Wisata Adat Using Kemiren. Masyarakat adalah sumber daya utama sebab yang memiliki serta menjalani keseharian adat adalah masyarakat. Sehingga dengan demikian, berkembang atau tidaknya Desa Wisata Adat Kemiren sangat tergantung pada kemauan dari Masyarakat sendiri. Apabila ditinjau secara langsung, Masyarakat Kemiren memang memiliki antusiasme yang begitu luar biasa dalam melestarikan adat serta budaya Using. Selain itu, masyarakat juga terus mengembangakan peluang-peluang aktivitas ekonomi dengan menggerakan usaha-usaha yang menjadi kebutuhan wisatawan seperti took oleh-oleh, warung makan, homestay dan lain sebagainya. Antusiasme Masyarakat Kemiren ini tergambar dari 43 homestay, 5 warung makan setara restaurant, sanggar seni seluas 7.000 meter persegi, 10 rumah adat heritage, took cinderamata dan lain sebagainya.

Antusiasme Masyarakat Kemiren ini tentu harus didukung oleh pihak-pihak terkait terutama para pemiliki modal. Sebab tentu potensi yang dimiliki Masyarakat akan lebih maksimal lagi apabila ada sokongan terutama berupa material. Oleh sebab itu, dibutuhkan kolaborasi dengan lebih banyak pihak agar dapat melihat potensi yang ada di Kemiren.

3. Akademisi

Peran akademisi dalam konsep Penta Helix sejatinya lebih mengarah pada pendampingan kepada pemerintah desa dan masyarakat terutama dalam hal penelitian. Sebab dalam hal pengembangan Desa Wisata Adat Kemiren, tidak bisa dilepaskan dengan kebijaka-kebijakan pemerintah. Disinilah peran akademisi sangat dibutuhkan, sebab tentu akademisi lebih memahami bagaimana alur dalam penetapan kebijakan mulai dari observasi hingga evaluasi. Sementara jika dihubungkan dengan masyarakat, akademisi berperan pada fasilitator dalam memahamkan masyarakat mengenangi perkembangan tantangan yang dihadapi saat ini seperti contoh digitalisasi. Sejauh ini apabila ditinjau secara langsung, hampir rata-rata akademisi yang datang ke Kemiren dan melakukan Penelitian karena akademisinya yang membutuhkan penelitian tersebut. Padahal tentu yang diharapkan adalah dampak dari penelitian yang dilakukan tidak hanya berhenti sampai pada literasi saja, akan tetapi juga sampai pendapingan kepada Masyarakat Kemiren.

\section{Swasta}

Swasta dalam konsep Penta Helix dapat dipahami sebagai aktor yang bertindak pada ranah industrialisasi pariwisata. Peran inilah yang akan menjadi pengembangan wisata menjadi terus bertumbuh. Dalam hal industrialisasi pariwisata, swasta memiliki cakupan yang begitu luas, mulai dari penyedia layanan akomodasi, investasi di bidang penginapan, wisata kuliner, dan potensi wisata desa lainnya. Secara sederhana dapat dikatakan bahwa selama ada keinginan, seluruh sektor dalam pariwisata dapat disentuh dan dikembangkan oleh swasta. Sementara ketika dikonfirmasi oleh peneliti, Kepala Desa Kemiren menjelaskan bahwa memang pemerintah desa belum memiliki program pokok kerjasama dengan pihak swasta atau bisa dikatakan kerjasama dengan pihak swasta masih sangat minim. Namun ia mengatakan bahwa yang menjadi 
fokus pemerintah desa adalah peningkatan prestasi dan kualitas sumber daya wisatanya. Sehingga apabila modalnya sudah baik, pihak swasta akan datang dengan sendirinya. Sejauh ini yang ada hanya sebatas bantuan yang disalurkan oleh swasta sebagai wujud apresiasi terhadap pelestarian budaya di Kemiren. Seperti bantuan dari Bank BRI cabang Jawa Timur yang membangunkan fasilitas-fasilitas publik dan lain sebagainya.

Apabila melihat potensi yang dimiliki oleh Kemiren, tentu peluang kerjasama dengan pihak swasta sangat terbuka lebar. Apalagi saat ini sudah bukan lagi masanya saling berkompetisi akan tetapi sudah berganti ke masa saling berkolaborasi. Sehingga keadaan ini harusnya mendorong terutama pihak Pemerintah Desa Kemiren dan juga Masyarakat membuka peluangpeluang kerjasama disamping terus meningkatkan prestasi dan kualitas sumber daya wisatanya.

5. Media Massa

Peran utama yang dibawakan sektor media massa adalah sebagai media promosi dan pembentuk brand image. Promosi menjadi penting bagi Kemiren sebab dengan promosi, maka potensi wisata yang dimiliki akan bisa diketahui oleh Masyarakat luas. Disamping itu, pembentukan brand image juga harus menjadi perhatian, sebab dengan adanya brand image Masyarakat luas akan mengetahui hal unik apa yang bisa dinikmati. Apabila promosi serta brand image sudah terbangun dengan baik. Maka akan semakin banyak wisatawan yang datang dan semakin besar pula aktivitas perekonomian. Sejauh ini, apabila melihat geliat pemanfaatan media massa oleh pemerintah desa dalam hal ini Pokdarwis sudah sangat baik, bisa dilihat dari pengelolaan website desa, media sosial desa, fasilitas digital yang ada di setiap destinasi wisata dan lain sebagainya. Akan tetapi tentu masih ada banyak hal yang bisa lebih dimaksimalkan lagi seperti kerjasama dengan media massa baik tingkat regional, nasional bahkan internasional.

Berdasar pada fakta-fakta di lapangan yang telah peniliti jabarkan diatas, maka perlu adanya kesadaran bersama serta political will terutama pemerintah desa agar bisa membuka lebih besar lagi potensi pemanfaatan serta pengembangan wisata desa. Melalui konsep Penta Helix dengan melibatkan lebih banyak aktor, maka akan lebih besar lagi tingkat kesejahteraan yang akan didapatkan.

\section{KESIMPULAN}

Dari hasil penelitian yang sudah dilakukan, penulis dapat menyimpulkan beberapa poin hasil temuan dalam pengembangan Desa Wisata Adat Using Kemiren Kecamatan Glagah Kabupaten Banyuwangi. Bahwa sejauh ini, pengembangan potensi wisata di Kemiren dapat dikatakan sudah baik, akan tetapi ada beberapa hal yang perlu menjadi perhatian pemerintah desa agar ke depan Desa Wisata Adat Using Kemiren terus berkembang dan mampu menghadapi tantangan di masa depan. Dalam konsep Penta Helix, dibutuhkan lima pemangku kepentingan yang saling berkolaborasi dalam mewujudkan tujaun bersama. Dalam kasus pengembangan Desa Wisata Adat Using Kemiren, sejauh ini peran yang terlihat masih sebatas pemerintah desa dan Masyarakat Kemiren saja. Alangkah lebih maksimalnya pengembangan Desa Wisata Adat Using Kemiren apabila dapat mengkolaborasikan kelima aktor dengan tugasnya masing-masing. Tahapan bisa dimulai dengan kajian pemahaman oleh akademisi kepada pemerintah desa dengan masyarakat tentang bagaimana konsep Penta Helix dijalankan. Lalu kemudian pemerintah desa sebagai fasilitator yang bertindak dalam mengkolaborasikan kelima aktor diatas dengan tetap di dampingi oleh akademisi.

Inovasi menjadi satu hal yang begitu penting untuk menjaga keberlangsungan pengembangan Desa Wisata Adat Using Kemiren. Sebab tantangan yang dihadapi akan selalu berubah, sehingga membutuhkan iklim inovasi yang berkelanjutan agar dapat meningkatkan pengembangan Desa Wisata Adat Using Kemiren. Menjaga iklim inovasi ini bisa dilakukan dengan cara studi dengan daerah lainnya yang memiliki inovasi-inovasi baru terutama di bidang pariwisata. Sehingga Pemerintah Desa Kemiren akan memiliki banyak referensi dalam menetapkan langkah inovasi apa yang akan ditetapkan kedepannya. 


\section{REFERENSI}

Andayani, A. A. I., Martono, E., \& Muhamad, M. (2017). Pemberdayaan masyarakat melalui pengembangan desa wisata dan implikasinya terhadap ketahanan sosial budaya wilayah (studi di desa wisata Penglipuran Bali). Jurnal Ketahanan Nasional, 23(1), 1-16.

Atmoko, P. H. (2014). Strategi Pengembangan Potensi Desa Wisata Brajan Kabupaten Sleman . Jurnal Media Wisata, Vol. 12, No. 2. 12(2), 4-13.

Brata, I. B. (2016). Kearifan budaya lokal perekat identitas bangsa. Jurnal Bakti Saraswati (JBS), $5(1)$.

Dwi, M., \& Muallidin, I. (2020). Strategi Lembag Adat dalam Pemanfaatan Teknologi Informasi dalam Pengambangan Pariwisata di Desa Adat Using Kemiren. Jurnal Pemerintah dan Kebijakan, 2(1), 8-12.

Halibas, A. S., Sibayan, R. O., \& Maata, R. L. R. (2017). The Penta Helix Konsep Of Innovation In Oman: An Hei Perspective. Interdisciplinary Journal of Information, Knowledge \& Management, 12.16(2), 34-43.

Hayat., \& Amalia, L. (2019). Penguatan Budaya Andep Ashor dan Patronisasi Masyarakat Madura. Jurnal Inovasi Ilmu Sosial dan Politik, 1(1), 38-42.

Kirk, J., Miller, M. L., \& Miller, M. L. (1986). Reliability and validity in qualitative research (Vol. 1). Sage.

Kusniawati, D., Islami, N. P., Setyaningrum, B., \& Prasetyawati, E. (2017). Pemberdayaan masyarakat berbasis potensi lokal melalui program desa wisata di Desa Bumiaji. Sosioglobal: Jurnal Pemikiran dan Penelitian Sosiologi, 2(1), 59-72.

Lestari, G. (2016). Bhinnekha Tunggal Ika: Khasanah Multikultural Indonesia Di Tengah Kehidupan SARA. Jurnal Ilmiah Pendidikan Pancasila Dan Kewarganegaraan, 28(1).

Pantiyasa, I. W. (2011). Pengembangan Pariwisata Berbasis Masyarakat (Community Based Tourism) Dalam Pemberdayaan Masyarakat (Studi Kasus Di Desa Bedulu, Blah Batuh, Gianyar). Jurnal Ilmiah Hospitality Management, 1(2).

Prasiasa, D. P. O. (2013). Destinasi pariwisata berbasis masyarakat.

Rusyidi, B., \& Fedryansah, M. (2018). Pengembangan pariwisata berbasis masyarakat. Focus: Jurnal Pekerjaan Sosial, 1(3), 155-165.

Sastrayudha, G. (2010). Handout Konsep Pengembangan Desa Wisata FPIPS UPI, 11.

Setyaningrum, N. D. B. (2018). Budaya lokal di era global. Ekspresi Seni: Jurnal Ilmu Pengetahuan dan Karya Seni, 20(2), 102-112.

Suparlan, P. (2014). Bhinneka Tunggal Ika: Keanekaragaman Sukubangsa atau Kebudayaan?. Antropologi Indonesia.

Trisnawati, A. E., Wahyono, H., \& Wardoyo, C. (2018). Pengembangan desa wisata dan pemberdayaan masyarakat berbasis potensi lokal. Jurnal Pendidikan: Teori, Penelitian, Dan Pengembangan, 3(1), 29-33.

Undang-undang Nomor 6 Tahun 2014 tentang Desa. 